\title{
SPREMINJANJE URBANE RABE TAL V LJUBLJANI
}

\author{
Marko Krevs \\ Oddelek za geografijo, Filozofska fakulteta v Ljubljani, Aškerčeva 2, \\ I000 Ljubljana, Slovenija, \\ e-mail: marko.krevs@ff.uni-lj.si
}

\section{Izvleček}

Predstavljeni so napori za izboljšanje poznavanja mestne rabe tal v Ljubljani ter problemi in perspektive spremljanja najnovejših procesov spreminjanja izbranih kategorij mestne rabe tal v mestu, mestni občini in mestni regiji.

Ključne besede: mestna raba tal, geoinformatika, Ljubljana.

\section{URBAN LANDUSE CHANGE IN LJUBLJANA}

\begin{abstract}
Efforts to improve the knowledge of urban landuse in Ljubljana, and recent problems and perspectives of monitoring the processes of changing of the selected categories of urban landuse in city, municipality and urban region are presented.
\end{abstract}

Key words: urban landuse, geoinformatics, Ljubljana. 


\section{UVOD}

Namen prispevka je soočiti pomen poznavanja spreminjanja mestne rabe tal v Ljubljani, problematičnost obstoječih virov in metod za njeno spremljanje, ter možnosti za izboljšave tega pomembnega strokovnega in upravljalskega področja.

Proučevanje rabe tal ima $\mathrm{v}$ slovenski geografiji razmeroma dolgo tradicijo, $\mathrm{z}$ začetki $\mathrm{v}$ letih po drugi svetovni vojni. Pregled tovrstnih raziskav (Gabrovec, Kladnik, 1997) kaže, da se je večina avtorjev ukvarjala $\mathrm{z}$ rabo tal $\mathrm{v}$ povezavi s kmetijsko in gozdarsko dejavnostjo na podeželskih območjih, na lokalni ravni in na podlagi podatkov iz zemljiškega katastra. Le redke raziskave obravnavajo problematiko rabe tal za celotno ozemlje Slovenije, na podlagi terenskega kartiranja ali zajema na podlagi daljinsko zaznanih gradiv (letalskih ali satelitskih posnetkov). Med raziskavami nismo našli nobene, ki se bi celoviteje in podrobneje ukvarjala s problematiko opredeljevanja in spremljanja spreminjanja rabe tal v mestih.

Poznavanje rabe tal v mestu nam omogoča predstavitev prostorske razmestitve različnih vrst oziroma načinov uporabe mestnih zemljišč. Tovrstne informacije morda najpogosteje vidimo na mestnih kartah, na katerih so predstavljene vsaj nekatere izmed temeljnih kategorij mestne rabe tal. $\mathrm{V}$ geografski literaturi pa je obravnava rabe tal $\mathrm{v}$ mestih pogosto povezana z njihovo morfološko in funkcijsko zgradbo, ter s spremljanjem in načrtovanjem prostorskega in funkcijskega spreminjanja mesta. $\mathrm{V}$ prostorsko-planerski literaturi in raziskavah je raba tal povezana z zemljiško in infrastrukturno politiko, trgom nepremičnin, med drugim tudi v povezavi s ponudbo nepremičnin za razvoj določenih (mestnih) funkcij. Podrobno in ažurno poznavanje mestne rabe tal je torej nujno tako za spremljanje in vrednotenje razvoja mesta, kot za njegovo načrtovanje.

Dejansko poznavanje spreminjanja mestne rabe tal v Sloveniji in tudi v Ljubljani žal ne ustreza pomenu, ki mu ga pripisujemo. Glavni težavi za doslej uporabljene pristope k spremljanju spreminjanja mestne rabe tal predstavljata:

- zahteva po vsebinski in prostorski podrobnosti zajema rabe tal; za mestno rabo tal je namreč značilna bistveno večja vsebinska in prostorska razdrobljenost, kot za podeželska območja;

- zahteva po primerljivosti podatkov o rabi tal med različnimi časovnimi prerezi za določeno območje.

Med temeljnimi metodološkimi problemi sedanjega proučevanja mestne rabe tal v Sloveniji je neustrezna kakovost podatkov v zemljiškem katastru ${ }^{1}$, na podlagi katerega bi bilo načeloma mogoče opredeliti velik del temeljnih kategorij rabe mestne tal. $Z$ vidika večine zgoraj omenjenih uporabnikov tovrstnih informacij sta predvsem »kritični« nekakovost vsebinskih (atributnih) podatkov ter neažurnost, nekoliko manj pa pozicijska natančnost podatkov. Zelo pomembna pomanjkljivost tega vira $\mathrm{z}$ vidika spremljanja procesa spreminjanja rabe tal je, da na Geodetski upravi RS ne hranijo časovnih prerezov stanj v zemljiškem katastru, niti za parcele, niti za katastrske občine.

\footnotetext{
${ }^{1}$ Digitalni katastrski načrt (DKN), Geodetska uprava Republike Slovenije.
} 
Posledica nekakovosti in - z vidika obravnavane tematike - vsebinske nepopolnosti temeljnega vira informacij o mestni rabi tal je potreba po iskanju alternativnih in dopolnilnih virov podatkov in metod za njihovo interpretacijo, ki se odraža v številnih raziskavah. Med raziskavami in znanstvenimi delavnicami, ki so bile pred kratkim izvedene ali še potekajo, se s problematiko ukvarjajo na primer $»$ Regionalna primerjava spreminjanja poselitvene rabe zemljišč med statističnimi regijami v Sloveniji v obdobju 1991-2002« (Krevs, Topole, 2004-2005 $)^{2}$, »Dinamika spreminjanja kategorij poselitvene rabe zemljišč v Sloveniji v obdobju 1991-2002« (Krevs, 2004), »Applicability of remote sensing in research of urban landuse« (Krevs, Palencsar, Altziebler, Mandl, 2003), »Zasnova stavbnih zemljišč v prostorskem planu Slovenije in državna stavbno zemljiška politika« (Bogataj, 2002). Splošna spoznanja o uporabnosti posameznih virov podatkov za proučevanje rabe tal so v nadaljnjem besedilu večinoma povzeta iz druge navedene raziskave (Krevs, 2004).

\section{ALTERNATIVNI IN DOPOLNILNI VIRI PODATKOV O POKROVNOSTI IN RABI TAL}

Med temeljne alternativne vire podatkov o pokrovnosti in deloma tudi rabi tal ${ }^{3}$ sodijo predvsem interpretirani daljinsko zaznani podatki, kataster stavb, zbirka podatkov o prometni in drugi infrastrukturi. Med dopolnilne vire podatkov, ki v kombinaciji s prej navedenimi omogočajo podrobnejše ločevanje (pod)kategorij rabe tal, pa sodijo na primer register prebivalstva, poslovni register, pa tudi podatki, pridobljeni s terenskim opazovanjem.

Kljub temu, da je tehnologija daljinskega zaznavanja znana že več desetletij in so se daljinsko zaznani podatki zelo pogosto uporabljali na primer za potrebe kmetijstva, gozdarstva, načrtovanje in spremljanje večjih posegov v prostor, je bila ta tehnologija in metodologija le redko uporabljena za proučevanje rabe tal v mestih. Opaznejši razvoj na slednjem področju se odvija šele v zadnjih letih (Jürgens, 2001, 2002, 2003; Mesev, 2003).

Za proučevanje mestne rabe tal so najpogosteje v rabi tri vrste daljinsko zaznanih podatkov: večspektralni satelitski posnetki s prostorsko ločljivostjo okoli 20-30 m, v ortofoto "predelani« letalski posnetki s prostorsko ločljivostjo $2 \mathrm{~m}$ ali manj, ter pankromatski in večspektralni satelitski posnetki z visoko ločljivostjo (primerljivo z ločljivostjo ortofota). Navedeni viri podatkov terjajo različne pristope k vsebinski razlagi podatkov ter posledično tudi različne metode in geoinformacijska orodja. Kljub različnim obstoječim državnim ali mestnim evidencam $v$ že omenjeni literaturi po svetu beležijo naraščanje zanimanja za različne alternativne vire podatkov o rabi tal, razvoj ponudbe tovrstnih podatkov in ustreznega znanja za njihovo učinkovitejšo uporabo.

\footnotetext{
${ }^{2}$ To sta dva projekta (CRPa) s skupnim glavnim naslovom, ki je naveden zgoraj med besedilom. Oddelek za geografijo Filozofska fakultete v Ljubljani (nosilec Krevs) proučuje izbrana mestna in obmestna območja, Geografski inštitut Antona Melika ZRC SAZU (nosilka Topole) pa izbrana podeželska območja. Raziskavi sta v začetni fazi.

${ }^{3}$ Pokrovnost tal pove, kaj (kateri material oziroma kakšen »pokrov«) pokriva posamezen del zemeljskega površja. Raba tal pa pove namen uporabe tega dela zemeljskega površja. Na primer, betonska ploščad predstavlja kategorijo pokrovnosti tal, ki pa je glede na rabo lahko na primer športno igrišče, skladišče na prostem, parkirišče.
} 
V Sloveniji obstajajo trije alternativni viri o pokrovnosti in rabi tal: Corine Land Cover (za leti 1996 in 2001, na podlagi satelitskih posnetkov Landsat TM in ETM), Zajem rabe kmetijskih zemljišč (2002, na podlagi ortofota) in Statistični GIS pokrovnosti in rabe tal Slovenije, ki je bil izdelan za leta 1993, 1997 in 2001 (na podlagi na podlagi satelitskih posnetkov Landsat TM in ETM). Za vse navedene vire ugotavljamo (Krevs, 2004), da je njihova uporabnost za opredeljevanje ali celo spremljanje mestne rabe tal zelo omejena. Za prvega izmed navedenih virov je na primer značilna zelo groba prostorska ločljivost, za drugega relativno dosledno in podrobno izveden zajem za območja izven naselij, medtem ko so poseljena območja in prometnice združene v eno samo kategorijo ${ }^{4}$. Pomembno pomanjkljivost drugega vira predstavlja tudi časovna nehomogenost letalskih posnetkov, $\mathrm{s}$ katerih so podatki zajeti (posnetki iz obdobja 1997-2002). Največja pomanjkljivost tretjega vira, ki je zaradi treh časovnih prerezov videti najbolj obetaven za spremljanje spreminjanja mestne rabe tal, je omejena primerljivost med podatki za tri časovne prereze. Za vse tri časovne prereze je bila uporabljena kombinacija klasifikacije satelitskega posnetka in dopolnilnih podatkov (na primer o prometnih površinah, poseljenih območjih, vodnih površinah). Vendar je bila v prvem časovnem prerezu uporabljena klasifikacija izvedena s pomočjo različne metode, kot za leti 1997 in 2001, pa tudi nekateri dopolnilni podatki (na primer o poseljenih območjih) so bili uporabljeni na neprimerljiv način. Tudi primerjava med letoma 1997 in 2001 se ob podrobnejši proučitvi prehodov med posameznimi kategorijami pokrovnosti in rabe tal izkaže nekoliko problematična, deloma zaradi razlik v uporabljeni metodologiji za klasifikacijo posnetkov, deloma zaradi sprememb v prostorski ločljivosti uporabljenih satelitskih posnetkov (30 metrska ločljivost Landsat TM za leto 1993 in 1997, 20 metrska ločljivost Landsat ETM za leto 2001).

Na splošno lahko razmerje med širokimi (»združenimi«) kategorijami ${ }^{5}$ pokrovnosti oziroma rabe tal v Ljubljani, Mestni občini Ljubljana ter Ljubljanski mestni regiji (slednjo predstavimo kar z Osrednjeslovensko statistično regijo) leta 2001 opišemo na naslednji način (tabela 1; izračuni na podlagi Statističnega GIS-a pokrovnosti in rabe tal v Sloveniji 2001, SURS). Z ožanjem opredelitve območja Ljubljane se povečuje delež pozidanih, kmetijskih in drugih »zelenih površin «, vodnih, prometnih in »ostalih « površin, zmanjšuje pa se delež gozdnih površin. Sestava rabe tal v Ljubljanski mestni regiji je podobna povprečni sestavi rabe tal v Sloveniji; izrazito višji od slovenskega je le delež pozidanih površin, bistveno nižja pa sta deleža vodnih in ostalih površin. Raba tal na administrativnem območju naselja Ljubljana seveda bistveno odstopa od slovenske povprečne sestave rabe tal. Kmetijskih in drugih »zelenih površin« je v Ljubljani več za $30 \%$, vodnih površin za $41 \%$, prometnih površin je 2.6-krat toliko, pozidanih površin pa 10-krat toliko, kot v strukturi slovenske povprečne rabe tal. Bistveno nižja od slovenskih sta deleža vodnih in »ostalih « površin (za $58 \%$ oziroma $30 \%$ ). Kmetijske, »zelene« in gozdne površine skupaj predstavljajo kar dve tretjini skupne površine administrativnega območja naselja Ljubljana. To je sicer bistveno

\footnotetext{
${ }^{4} \mathrm{~V}$ seznamu predvidenih kategorij za zajem je bilo za poseljene in prometne površine predvidenih okoli 15 kategorij in podkategorij.

${ }^{5}$ Uporaba tako grobe kategorizacije je potrebna zaradi velikih razlik v podrobnejših kategorizacijah Statističnega GIS-a pokrovnosti in rabe tal Slovenije za posamezna leta.
} 
manj, kot 94\% v celotni Sloveniji, vendar kaže, da »zelene površine« (v širšem smislu) predstavljajo izredno velik dele mesta oziroma so prebivalstvu mesta lahko dostopne.

Procesi spreminjanja pokrovnosti oziroma rabe tal v Ljubljani v obdobju 1997-2001 pa so bili naslednji (tabela 1; izračuni na podlagi Statističnega GIS-a pokrovnosti in rabe tal v Sloveniji 1997 in 2001, SURS). Najintenzivneje so se povečevale prometne površine, kar lahko deloma povežemo z izrazitim zmanjšanjem »ostalih« površin. Del slednjih namreč predstavljajo tudi gradbišča, med temi pa so bila gradbišča južnega in vzhodnega dela obvoznice med prostorsko najbolj obsežnimi. Kmetijske in »zelene« površine so se v obravnavanem obdobju še povečevale $v$ mestu in Mestni občini Ljubljana, medtem ko so se $\mathrm{v}$ Ljubljanski mestni regiji in celotni Sloveniji izrazito zmanjševale. Zanimivo je, da so se pozidane površine $\mathrm{v}$ mestu in Mestni občini Ljubljana sicer nekoliko povečale (za $0.4 \%$ oziroma $0.8 \%$ ), vendar bistveno manj, kot v Ljubljanski mestni regiji ali Sloveniji (za 3\% oziroma 2.9\%). Naslednja zanimivost je izrazito zmanjšanje gozdnih površin v mestu in Mestni občini Ljubljana (za $11 \%$ oziroma 4.7\%). Podrobnejša proučitev prehodov med kategorijami pokrovnosti in rabe tal pokaže, da so se na račun zmanjšanja gozdnih površin povečale predvsem površine kmetijskih in drugih »zelenih« površin.

Tabela 1: Deleži površin leta 2001 in indeksi sprememb med letoma 1997 in 2001 po združenih kategorijah pokrovnosti oziroma rabe tal v Ljubljani, Mestni občini Ljubljana in Ljubljanski mestni regiji.

Table 1: Percentages of areas in 2001 and indices of changes between the years 1997 and 2001, by coarse categories of landcover and landuse in Ljubljana, Municipality of Ljubljana, and Ljubljana urban region.

\begin{tabular}{|l|r|r|r|r|r|r|} 
\% površine & $\begin{array}{c}\text { kmetijsko } \\
\text { zeleno }\end{array}$ & \multicolumn{1}{c|}{ gozd } & pozidano & \multicolumn{1}{c|}{ vode } & \multicolumn{1}{c|}{ ostalo } & promet \\
\hline Ljubljana & 40,57 & 26,04 & 28,38 & 0,94 & 1,11 & 2,96 \\
\hline Mestna občina Ljubljana & 35,56 & 43,10 & 17,64 & 0,75 & 0,81 & 2,15 \\
\hline Ljubljanska mestna regija & 30,77 & 62,38 & 4,38 & 0,33 & 0,86 & 1,27 \\
\hline Slovenija & 31,26 & 62,60 & 2,75 & 0,66 & 1,60 & 1,13 \\
\hline \hline Indeks 1997-2001 & & & & & & \\
\hline Ljubljana & 107,3 & 89,0 & 100,4 & 99,7 & 89,9 & 120,1 \\
\hline Mestna občina Ljubljana & 105,3 & 95,3 & 100,8 & 100,4 & 89,0 & 115,9 \\
\hline Ljubljanska mestna regija & 95,4 & 101,5 & 103 & 100 & 174,3 & 104,9 \\
\hline Slovenija & 91,7 & 104,3 & 102,9 & 99,8 & 115,4 & 103,6 \\
\hline
\end{tabular}

Izračuni: Repe (v okviru raziskave Krevs, 2004). Vir podatkov: GURS, SURS.

Razlaga uporabljenih oznak za združene kategorije pokrovnosti oziroma rabe tal: kmetijsko+zeleno - njivske, travnate površine in ostale zelene površine, gozd - gozne površine, poz - pozidane površine, vode - vodne površine (tekoče, stoječe), ostalo - odprte površine (skale, neporaslo, deponije, kamnolomi), promet - ceste, železnice, letališča. 


\section{IZZIVI IN PERSPEKTIVE ZA NADALJNJE RAZISKOVANJE}

Kljub obstoju in uporabi številnih virov podatkov za proučevanje pokrovnosti in rabe tal, so dosedanji rezultati skromni. Lahko trdimo, da so slabši, kot bi bili v primeru boljše kakovosti in ustreznega hranjenja podatkov (v obliki časovnih prerezov) iz enega samega vira zemljiškega katastra. Obenem pa trdimo, da bo obstajala potreba po alternativnih in dopolnilnih podatkih tudi, ko bo omenjeni vir podatkov ustreznejše kakovosti. Glavna razloga za slednjo trditev sta naslednja. Zemljiški kataster se lahko razmeroma močno približa evidenci dejanske rabe tal, vendar nikdar v celoti. Za proučevanje spreminjanja rabe tal so dosedanji podatki iz zemljiškega katastra neustrezna podlaga za primerjavo z bodočimi stanji in na tej podlagi ugotavljanje procesov spreminjanja med posameznimi kategorijami rabe tal.

Vendarle lahko prav opisane trenutne »nesrečne okoliščine« vidimo kot izziv za nadaljnje raziskovanje mestne oziroma poselitvene rabe tal, iskanje novih virov podatkov ter zavzemanje za izboljšanje nekaterih državnih evidenc.

Slika 1: Indeks NDVI, izračunan iz prostorsko relativno grobih posnetkov Landsat ETM (ločljivost $20 \mathrm{~m}$ ) iz leta 2002, s preprosto nadaljnjo obdelavo omogočajo razmeroma podrobno ločevanje pozidanih in »zelenih « površin.

Figure 1: Simple further analysis of NDVI, based on spatially relativelly coarse Landsat ETM images (spatial resolution of 20 meters) from the year 2002, provides us with relativelly efficient division between the built-up and "green« areas.

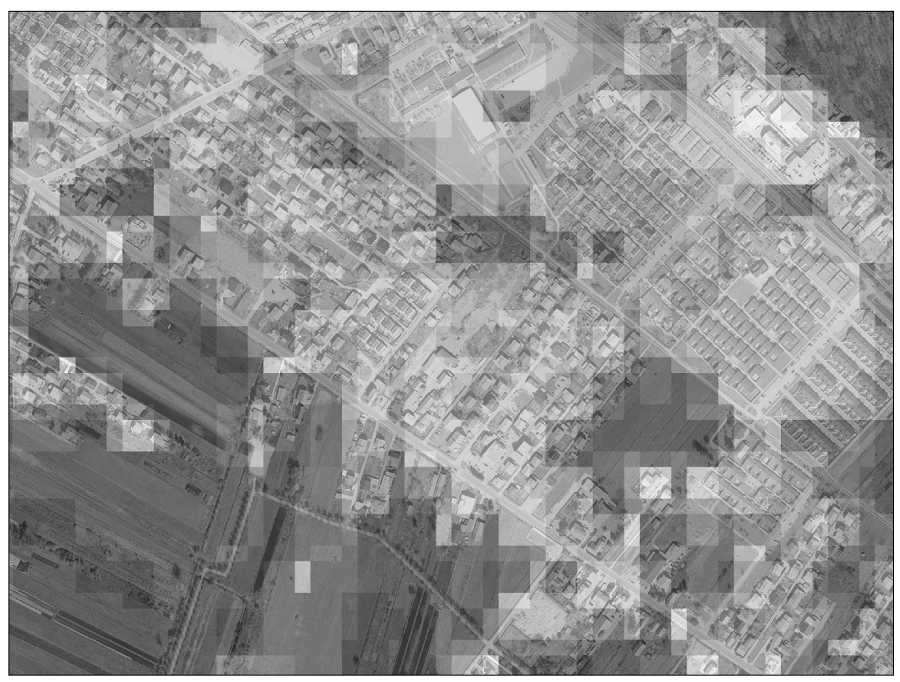

Vir: Krevs, 2004, neobjavljeni vmesni rezultati. Vir podatkov: SURS, Landsat ETM.

Posodabljanje in izpopolnjevanje slednjih, med njimi tudi zemljiškega katastra, se odvija v okviru vzpostavljanja sistema e-Uprave v Sloveniji. Težave teh sprememb niso zgolj tehničnega ali strokovnega značaja. Poleg obilice napak, ki so se iz različnih vzrokov nakopičile v katastru, so problematični tudi upravni postopki, povezani z evidentiranjem sprememb. 
$\mathrm{Z}$ vidika proučevanja rabe tal je zelo pomembno, da podatki v katastru časovno čim manj od-stopajo od dejanske rabe tal. Zagotoviti bi bilo torej treba mehanizme, ki bi zmanjševali to pomanjkljivost vira. $S$ tem bi država pridobila ne le realnejše podlage za obdavčenje zem-ljišč, temveč tudi podlago za spremljanje in realnejše načrtovanje rabe tal.

Drugo področje mogočih izboljšav bi lahko bila ponovna, metodološko primerljiva analiza podatkov, na podlagi katerih je bil izdelan Statistični GIS pokrovnosti in rabe tal Slovenije za leta 1993, 1997, 2001 (zlasti za prvo leto). Sistematično bi veljalo preizkusiti tudi uporabo vegetacijskih indeksov (na primer NDVI, slika 1; glej tudi Krevs, 2004). Izraziti prednosti tovrstnih satelitskih posnetkov pred cikličnimi letalskimi snemanji je bistveno boljša časovna homogenost snemanja ter snemanje v več delih spektra hkrati, kar omogoča zanesljivejše ločevanje različnih kategorij rabe tal med seboj. V skladu s sodobnimi trendi v proučevanju (mestne) rabe tal pod »pokroviteljstvom« Statističnega urada RS v različnih ustanovah in strokah ravno poteka preizkušanje večspektralnih satelitskih posnetkov visoke ločljivosti Quickbird na območju Vzhodne Ljubljane.

Kljub nekaterim metodam, ki omogočajo metodološki napredek v smeri večje avtomatizacije postopkov prepoznavanja rabe tal $\mathrm{z}$ daljinsko zaznanih podatkov, bo tudi v bodoče vizualna interpretacija predstavljala pomemben vir podatkov o rabi tal, zlasti za relativno majhna območja (Breg, 2003; Rozman in drugi, 2003; sliki 2 in 3). Med šibkosti tovrstnega zajema rabe tal sodi predvsem možnost subjektivnega vpliva na določanje kategorij rabe tal.

Slika 2: Podrobna fotointerpretacija na podlagi primerjave starega in novega posnetka za isto območje.

Figure 2: Detailed photo-interpretation based on comparison of older and new ortophoto image of the same area.

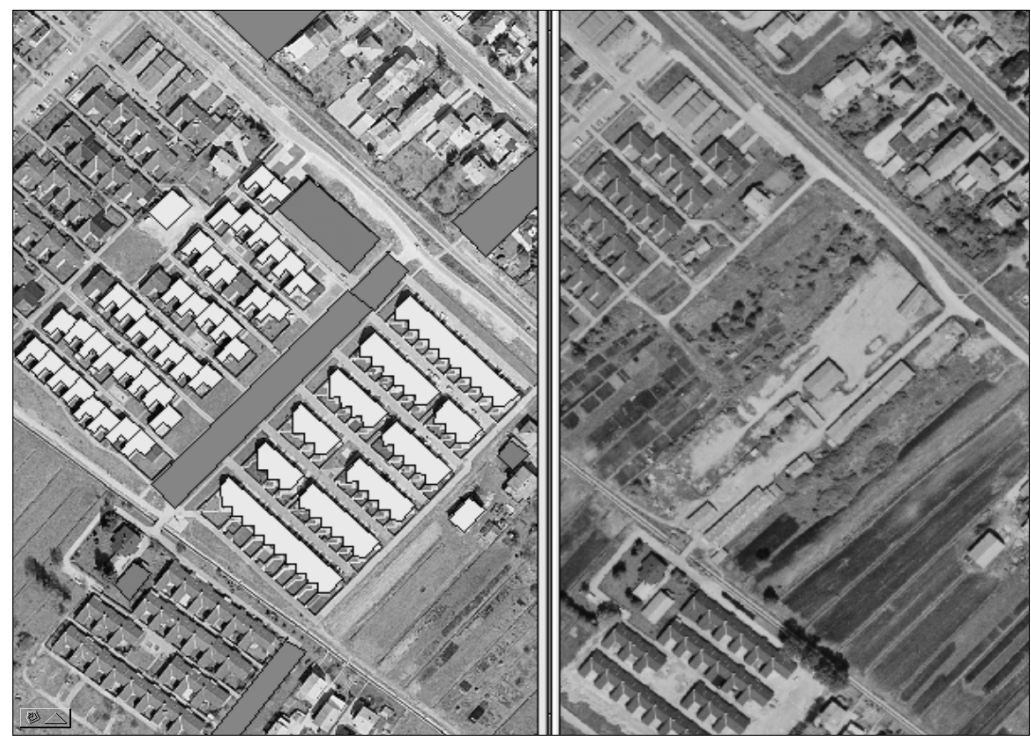

Vir: Rozman in drugi, 2003. Vir podatkov: GURS. 
Med iskanja v smeri izboljšanja kakovosti samega zajema rabe tal, ali njegove razlage, lahko na primer uvrstimo tudi preizkušanje poševnih in navpičnih stereo posnetkov iz balona (Krevs in drugi, 2003; slika 4), kombiniranje daljinsko zaznanih podatkov s podatki o »uporabnikih prostora« (na primer o prebivalstvu, poslovnih in javnih dejavnostih) ali »značilnostih območij« (na primer o reliefu; lahko tudi le za nazornejšo vizualizacijo). Navedeni poskusi, predvsem pa nadaljnje delo v okviru omenjenih raziskav (Krevs, Topole, 2004-2005; Pichler Milanovič, 2003) naj bi že v prihodnjem letu prinesli podrobnejša spoznanja o spreminjanju rabe tal v Ljubljani in njeni mestni regiji.

Slika 3: Zajem rabe tal (a) za leti 1992 in (b) 2002 ter (c) raba tal v Prostorskih zasnovah Prostorskega plana Mestne občine Ljubljana (2002) za isto območje. Za podlago je na prvih dveh slikah prikazan ortofoto za leto 2002.

Figure 3: Landuse acquision for the years (a) 1992 and (b) 2002, and landuse map from spatial concepts of spatial plan of municipality of Ljubljana (2002) of the same area. As background for the first two images ortophoto from 2002 is used.

a)

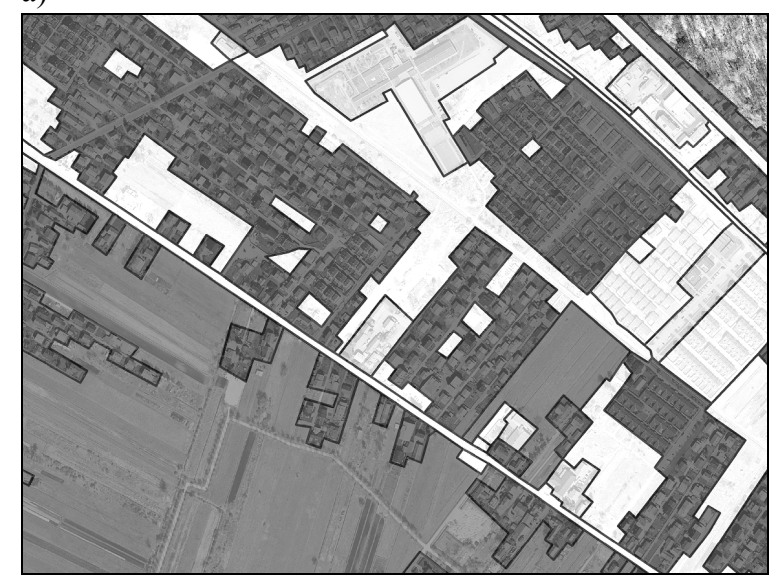

b)

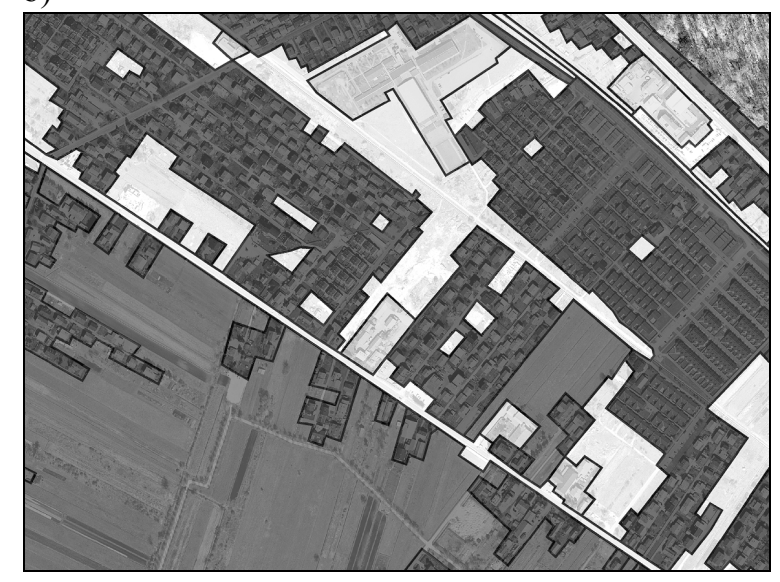


c)

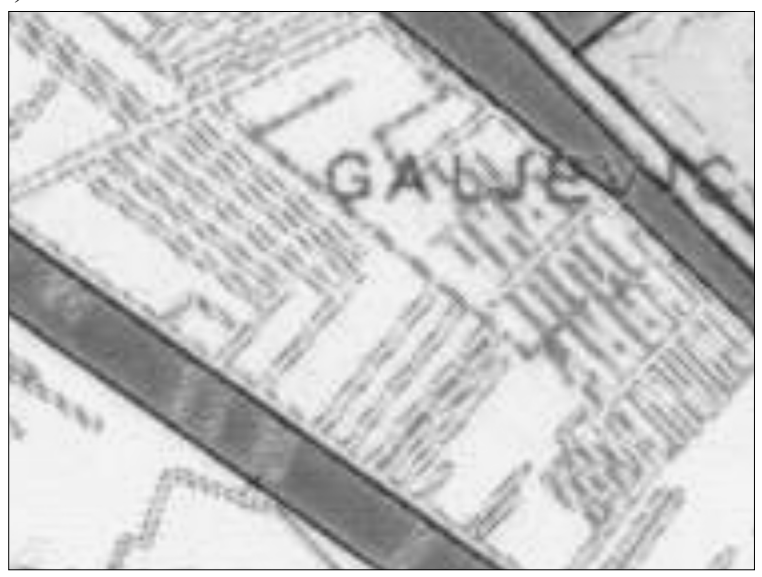

Vir: Krevs, 2004 in Pichler Milanovič, 2003; neobjavljeni vmesni rezultati projektov; Prostorske zasnove, Prostorski plan Mestne občine Ljubljana, 2002. Vir podatkov: GURS, 1992 in 2002.

Slika 4: Poševni posnetek iz balona omogoča boljše vsebinsko razpoznavanje rabe tal na relativno majhnih območjih.

Figure 4: Oblique remotely sensed image, taken from baloon, offers better possibilities for interpretation of landuse categories on relativelly small areas, than ortophoto.

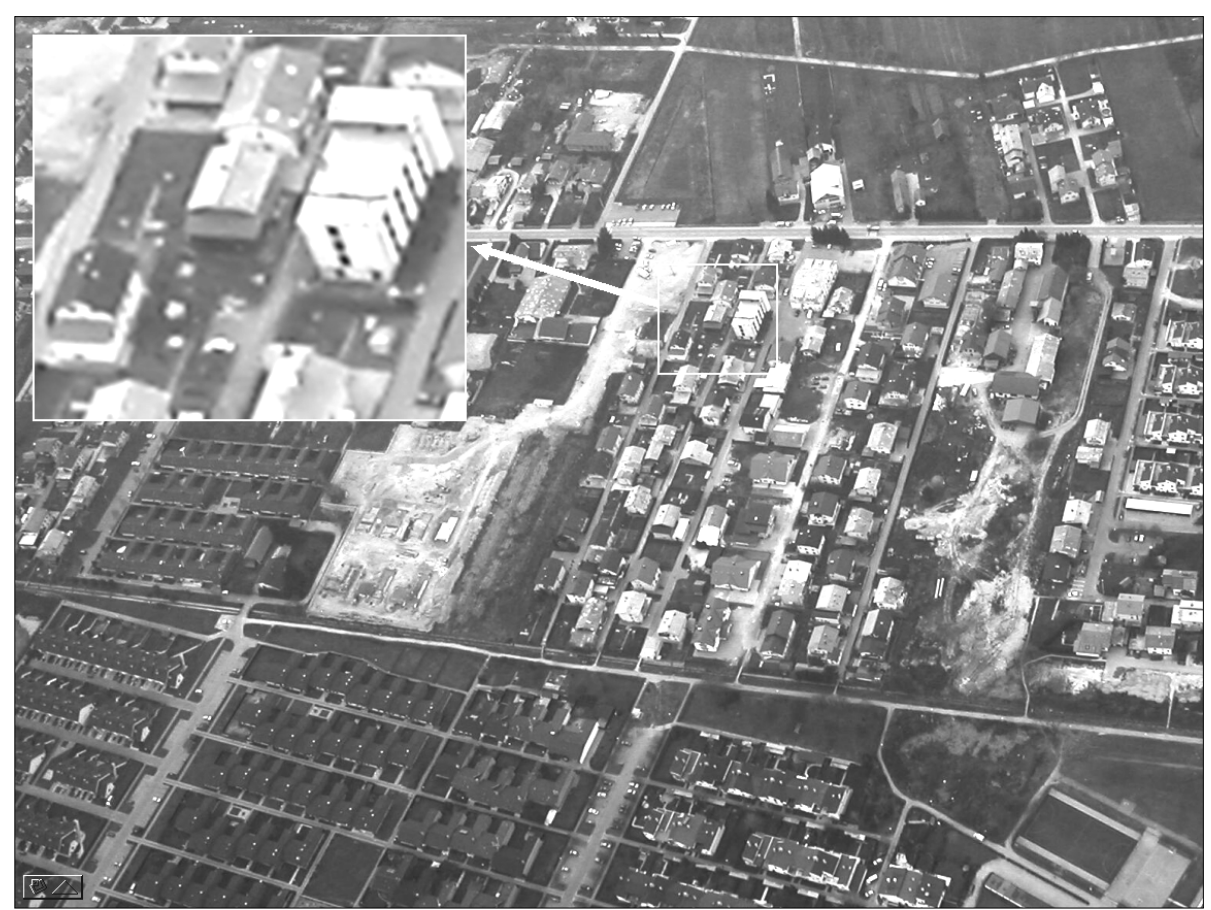

Vir: Krevs, Burger, Valant, Šorn, 2003. 


\section{Viri in literatura}

Bogataj, L. (nosilka), 2002: Zasnova stavbnih zemljišč v prostorskem planu Slovenije in državna stavbno zemljiška politika. Izvajalec: Univerza v Ljubljani, Fakulteta za pomorstvo in promet, CERRISK, Koper. Naročnik: Ministrstvo za okolje in prostor Republike Slovenije, Urad RS za prostorsko planiranje.

Breg, M. 2003: Razpoznavanje mestne rabe tal $\mathrm{z}$ digitalnega ortofoto posnetka na izbranih primerih v Ljubljani. Seminarska naloga, Oddelek za geografijo, FF v Ljubljani.

Corine Land Cover, 1996 in 2002. Geodetska uprava RS, Ljubljana.

Gabrovec, M., Kladnik, D. 1997: Nekaj novih vidikov rabe tal v Sloveniji. Geografski zbornik 37 (1997), 7-64.

Jürgens, C. 2001, 2002, 2003, Remote sensing of Urban Areas. Zborniki mednarodnih srečanj v Regensburgu in Istanbulu.

Krevs, M. (nosilec) 2004: Dinamika spreminjanja kategorij poselitvene rabe zemljǐ̌̌ v Sloveniji v obdobju 1991-2002. Zaključno poročilo raziskovalnega projekta. Izvajalec: Oddelek za geografijo, Filozofska fakulteta, Univerza v Ljubljani. Naročnik: Ministrstvo za okolje, prostor in energijo.

Krevs, M. 2003: Assessing and monitoring the urban land-use changes in Slovenia. V: Jürgens, C. (urednik), Remote sensing of urban areas. The international archives of the photogrammetry, remote sensing, and spatial information sciences XXXIV - 7/W9. Regensburg.

Krevs, M., Burger, B., Valant, J., Šorn, A.: Gradivo digitalnega fotografiranja izbranih območij Ljubljane z balona 10.12.2003.

Krevs, M., Palencsar, F., Altziebler, H., Mandl, P. 2003: Applicability of remote sensing in research of urban landuse. Gradiva za delavnico 16.6.2003, Oddelek za geografijo, Filozofska fakulteta v Ljubljani. Sodelovanje: Oddelek za geografijo, Filozofska fakulteta v Ljubljani, Institut für Geographie und Regionalforschung, Universität Klagenfurt. Mednarodno raziskovalno sodelovanje finančno podprto s strani Avstrijskega intituta za Vzhodno in Jugovzhodno Evropo ter Avstrijskega Ministrstva za znanost.

Mesev, V. (urednik) 2003: Remotely sensed cities. Taylor \& Francis.

Pichler Milanovič, N. (nosilka) 2003: (Ne)načrtno širjenje mestnega območja: izziv za trajnostni razvoj, urejanje in načrtovanje prostora. Vmesno poročilo 3. faze projekta CRP. Izvajalec: Urbanistični inštitut RS. Naročnik: MOPE, MŠZŠ, Ljubljana.

Rozman, P. in drugi, 2003: Širjenje pozidanih površin na izbranem primeru. Študentska raziskovalna naloga v okviru raziskav Krevs, 2004, Pichler Milanovič, 2003. Oddelek za geografijo FF v Ljubljani.

Statistični GIS pokrovnosti in rabe tal v Sloveniji, 1993, 1997 in 2001. Digitalni podatki v rastrski obliki. Statistični urad RS, Ljubljana.

Zajem rabe kmetijskih zemljišč, 2002. Digitalni vektorski podatki. Ministrstvo za kmetijstvo, gozdarstvo in prehrano RS, Ljubljana. 


\section{URBAN LANDUSE CHANGE IN LJUBLJANA}

\section{Summary}

Landuse research attracted attention of Slovenian geographers since WW II, but predominantly in relation to agricultural and forestry activities, focused on local studies of rural areas, ussually based on land cadastre data. No fundamental research has been done so far on urban landuse and it's change. However, recently the demand for information on landuse change in urban areas has grown, as well as the accessibility of diverse data sources, and geoinformatic tools. Beside cartographers (to produce city maps) and geographers, the spatial planners and the government (from national to local level) cause this demand.

The main problem of the urban landuse research in Slovenia, and Ljubljana, is relativelly poor quality of land cadastre data which could serve as the main source of data for such research. Additional problem with the same source is its focus on the current situation, without keeping data in time series, which makes the source useless for analysis of landuse change. Despite serious attempts to improve the quality of this source (within broader program of establishing e-Government), alternative and supplementary data sources are tested, and methods developed in order to acquire more reliable information and knowledge about urban landuse and it's change.

Among the alternative data sources, the interpreted remotelly sensed data, cadastre of buildings and database on transport and other infrastructure are used in the research projects. Supplementary data sources, used in combination with the above mentioned sources to improve detailed categorization of landuse, are e.g. registers of population and firms, and data collected by fieldwork techniques.

Among the activities aiming at better urban landuse research in Ljubljana, are testing and improving of fotointerpretation methods (on orthophoto images), analysing Quickbird high resolution satellite imagery, NDVI indices, and vertical and oblique stereo-imagery collected by half professional digital cameras from the balloon. Considerable improvements in the knowledge about the landuse changes in Ljubljana and it's urban region, mainly from research cooperation performed by Department of Geography, Faculty of Arts, University of Ljubljana, Geographical Institute of Anton Melik, ZRC SAZU from Ljubljana, and Urban Planning Institute of Republic of Slovenia, are expected in the next year. 